\title{
PJIEE
}

\author{
Premise : Journal of English Education and Applied Linguistics
}

https://fkip.ummetro.ac.id/journal/index.php/english

Fhaeizdhyall, and Jerome

\section{THE EFFECT OF WRITTEN CORRECTIVE FEEDBACK STRATEGIES ON COLLOCATION ERRORS OF LOW-PERFORMING ESL LEARNERS}

\author{
by
}

Abang Fhaeizdhyall

Faculty of Language and Communication, Universiti Malaysia Sarawak abang385@uitm.edu.my

\section{Collin Jerome}

Faculty of Language and Communication, Universiti Malaysia Sarawak jcollin@unimas.my

\begin{abstract}
:
The studies on error correction have been laying their emphasis on grammatical structures of the language with lack of focus on non-grammatical aspect such as lexical collocation. Therefore, this study aims at investigating the effect of direct and indirect written corrective feedback on lowperforming ESL learners. Ninety-two students of a public university involved in the study. Three intact groups that have equal proficiency were identified at the beginning of the university's academic term. A quasi-experimental design was employed with two experimental groups receiving indirect WCF and direct WCF separately, and a control group deprived of any treatment. The groups were measured in three different time points with pre-test before the intervention, immediate post-test after the intervention, and delayed post-test to measure retention effect. One-way ANOVA and repeated-measures ANOVA were used to measure the effect. The findings reveal that significant differences were detected in immediate post-tests of direct and indirect WCF groups which indicate that both WCF strategies can enhance participants' collocational competency. Additionally, the findings also show that direct WCF strategy greatly affects participants collocation errors despite both groups performed better than the control group. This study demonstrates that retention effect was detected in the group that received direct WCF while the indirect WCF group was not able to retain - in delayed post-test. Recommendation is also discussed for Future directions of studies.
\end{abstract}

Keywords: written corrective feedback, direct WCF, indirect WCF, English collocation, low-performing ESL learners.

\section{INTRODUCTION}

In the field of second language acquisition (SLA), two central questions of the role of Written corrective feedback (WCF) arises: should WCF be provided on learners linguistic errors in 